\title{
Hungarian Parallels to the Anecdotal Style of Švejk
}

\author{
Tibor Gintli
}

Eötvös Loránd Tudományegyetem, Bölcsészettudomány Kar, Múzeum krt.4-6,HU-Budapest, gintlitibor@gmail.com

SCN IX/1 [2016], 47-63

\begin{abstract}
Študija predstavlja vzporednice med madžarsko literarno anekdotično pripovedjo 20. stoletja in Švejkom. Predmet uvodnega dela analize so žanrovske komponente Haškovega romana, s katerimi želimo predstaviti prisotnost anekdotičnih posebnosti in njihove poetične funkcije. $\mathrm{V}$ nadaljevanju primerjamo anekdotične značilnosti $v$ treh romanih madžarskega pisatelja Jenőja Józsija Tersánszkyja (Zgodba o svinčniku, Marci Kakuk, Legenda o zajčjem paprikašu) z rešitvami v Haškovem romanu.
\end{abstract}

This study examines the parallels between $20^{\text {th }}$-century Hungarian anecdotal narration and the narrative of $\breve{S}$ vejk. First, the genre components of $\check{S} v e j k$ are examined in order to confirm the presence and function of anecdotal characteristics. The anecdotal elements of works by the Hungarian writer Józsi Jenő Tersánszky (The Story of a Pencil, the Kakuk Marci novels, The Legend of the Rabbit Stew) are then compared to Hašek's methods.

Ključne besede: anekdotični roman, ustna pripoved, epizodičnost, satira, subverzivni zorni kot

Key words: anecdotal novel, oral narration, episodic structure, satire, worm's-eye view

The present study explores the apparent connections between the narrative of the $20^{\text {th }}$-century Czech literary classic $\breve{S} v e j k$ and certain more or less concurrent phenomena in Hungarian literature that share common features with it. Thus, rather than examining the historical impact and effect of $\check{S} v e j k$, or the various references to it, the study will point out stylistic parallels to its prose in Hungarian literary works from the first third of the $20^{\text {th }}$ century. However, in order to successfully explore these connections, the question of Svejk's genre must first be addressed. 
Literary criticism has generally emphasized two traditions as major influences on the novel's genre components: Menippean satire (Steiner 2000: 37) and the picaresque novel (Kovach 1984: 251-261). Such parallels are certainly justifiable: the polarized, provocative perspective of $\breve{S} v e j k$ is scarcely independent from the tradition of the satirical narrative. The first Menippean satire, Seneca's Apocolocyntosis - the text of which has survived in its entirety-begins with a narration of how Emperor Claudius not only yielded his soul at the moment of his death, but also defecated while loudly passing wind. This blunt, physical humour was continued by Rabelais in Gargantua and Pantagruel, the title of which is mentioned by the narrative voice in Švejk. There is thus a clear reference to the literary antecedent that motivated Hašek in the comic depiction of defecation, vulgar humour and iconoclasm. ${ }^{1}$ Of course, the imitation of Menippean satire cannot be called rigorous - due, among other things, to the lack of alternation between verse and prose.

The situation is similar in terms of the genre components of the picaresque novel: while certain characteristics of the genre are evident in Švejk, other important features are either missing or have been fundamentally modified. Thus Hašek's book can be called a picaresque novel only in the broadest sense. Tomas Kovach convincingly summarized the picaresque components of the novel, also noting the significant fact that picaresque novels usually feature a retrospective, first-person narrator (Kovach 1984: 256). It is worth pointing out that the list of fundamental differences does not end here. Neither the characteristic events of the novel, nor the personality of Hašek's protagonist, correspond to the picaresque genre. The protagonist is not involved in reckless escapades, petty crimes, robberies or murders: he is, essentially, a mild-tempered man. The picaro, on the other hand, is of low social standing and is motivated by a desire to climb in social status and accumulate wealth. This trait is denied by the narrator only in retrospect, in his present-tense narration. Švejk, on the other hand, is essentially content with his situation and cherishes no grand aspirations. The picaro is cunning and calculating: it is his intelligence-along with his unscrupulousness - that helps him to achieve his goals. Švejk is repeatedly shadowed by stupidity, and attributing to him the role of "wise fool" does little to alter his image. Furthermore, humour is not a prerequisite of the picaresque novel. While such novels may contain humorous episodes, the tone of the text as a whole is not predominantly witty. The narrator is introduced as an adventurer mending his ways, a converted sinner, thus in a role that is hardly conducive to continuous laughter. Nevertheless, there can be no doubt that picaresque elements should be regarded as important components of the genre of Hašek's novel.

In literary criticism, references to anecdotalism are certainly made in examinations of the novel's genre. It is a commonplace that Švejk tells anecdotal

1 "The venerable father awoke in all his beauty and dignity. His awakening was accompanied by the same phenomena as the morning awakening of young giant Gargantua as described by gay old Rabelais" (Hašek 1985: 341). 
stories in the most varied situations. Nevertheless, anecdotalism may deserve even greater attention than other genre components of the novel. Hašek's work can be considered an anecdotal novel just as much as an example of picaresque or satire. In fact, a comparison of the three genres shows that the text of Švejk can be regarded as anecdotic with the fewest reservations. Strictly speaking, there is only one controversial issue - the fact that anecdotes are typically defined as short accounts. Some critics even question the existence of the anecdotal novel, arguing against the possibility of a transition from the short to the long form (Hajdú 2005: 206-207). Such an argument is difficult to maintain if works on the borderline between short story cycles and novels, composite novels, or the genre of the romance are taken into consideration. Differences in the length of the text present no obstacle to transition between genres. In Hungarian literary criticism there is a clear awareness of the concept of the anecdotal novel, which was a popular genre in $19^{\text {th }}$-century Hungarian fiction. The macro-plots of Kálmán Mikszáth's novels, for example, are often expanded anecdotes, while they also regularly include anecdotal digressions. His narrative itself also shows certain anecdotal characteristics: the style is either humorous or ironic; the narration imitates colloquial language; and the narrative is characterized by an atmosphere of familiarity. The novel depicts a world familiar to the narrator; the characters are almost personal acquaintances; and he often addresses the reader directly, in a casual, conversational tone. This tradition survived almost unchanged in the prose of more conservative Hungarian authors in the second half of the $20^{\text {th }}$ century, although some Hungarian writers reinterpreted the style in the spirit of modernity.

Anecdotes and anecdotal narration play an important role in Hašek's novel, and not only in Švejk's voice. The narrator often intersperses the narrative with anecdotal digressions. On one occasion, for example, he remembers how cats had been used to control mice in the military stores of the Monarchy. The cats were registered in the division "K.u.K. Militärmagazinkatze":

Earlier, in the reign of Maria Theresa, cats had been introduced into the military stores in wartime, when it was on the wretched mice that the gentlemen from the administration were blaming all their fiddles with uniforms.

But in many cases the Imperial and Royal cats failed to do their duties, and so it happened that once in reign of Emperor Leopold six cats which had been assigned to the military stores at Pohořelec were hanged by the verdict of a court-martial. I can imagine that on that occasion all those who had had anything to do with the military stores laughed smugly in their sleeves... (Hašek 1985: 684-685)

On other occasions, the first appearance of a new character provides grounds for an anecdotal digression, as is the case when Doctor Welfer enters the narrative. The doctor's function in the plot is to diagnose Cadet Biegler's diarrhoea. He briefly sums up his diagnosis to Captain Ságner as follows: "It's not cholera, it's not dysentery, it's just a common or garden shitting" (Hašek 1985: 503). While not unimportant, this function is not crucial and would not necessarily require a lengthy introduction. Nevertheless, the narrator describes Doctor Welfer 
in a two-page anecdote, from which the reader learns that he was a "pre-medic" before the war. His uncle left him an allowance in his will only until such time as he earned his degree in medicine. Although, after some time, Welfer acquired a profound understanding of medicine, he had no intention of completing his degree. When the war broke out he was immediately recruited into the army, and, despite giving a somewhat stereotypical and inadequate answer to every examination question (Lecken Sie mich am Arsch! "Kiss my arse!"), he was awarded a "military doctorate degree in medicine" against his will.

Besides the narrative tone, the structure of the plot is also characterized by anecdotal features. The various episodes in Švejk's life belong rather to the genre of anecdote than that of adventure. Excitement generated by apparent danger is not a defining element in the text: the reader gradually comes to a realization that the protagonist will escape from every peril unscathed. Even during the court case, when threatened with the death penalty, there is no doubt that Švejk will emerge from the danger as a result of another comic twist. Each stage in the story ends on a comic note, thus the plot is presented as a sequence of anecdotal episodes.

Švejk's narration, which forms the majority of the text, is augmented by the narrations of other characters. On the whole it can be said that the narrator's voice is somewhat overshadowed by these embedded narratives. Švejk's narrative style, like that of his fellow soldiers, is characterized by the use of everyday language. The embedded narratives do not represent colloquial style or the language of educated discourse, but a lower, everyday register spoken in Prague. František Daneš regards the inclusion of this level of language use in the narrative as an innovation, as, until the publication of Švejk after the war, the everyday Czech language had scarcely appeared in works of literature (Daneš 1993: 233). A comparison between the five-chapter version of the novel written before the war and the post-war version reveals that this innovation is a direct result of anecdotalism: "Comparing this 'primeval' Švejk with the famous post-war novel, we ascertain at first sight an essential difference: not only the amount of direct speech is considerably lower than in the novel (the author had preferred indirect speech) and the famous Švejk's narrations from the history of people's troubles are totally missing there, but Švejk is speaking the Standard Language with an admixture of colloquial elements and does not use Common Czech and vulgarism at all!" (Daneš 1993: 232-233). The language of the novel is changed significantly by Švejk-type anecdotal storytelling. The style of the protagonist's pub stories ${ }^{2}$ influences the narrator's voice, as, to a certain degree, some of its elements are derived from a similar stylistic layer. ${ }^{3}$

\footnotetext{
${ }^{2}$ Kovach quotes Emanuel Frynta's famous statement (Kovach 1984: 253).

3 "On the one hand, it may seem that Hašek follows the prescriptions of a rigorous Czech teacher with a puristic and traditional orientation, on the other hand, this school knowledge will be corroded and partly overridden by Hašek's natural feeling that this obsolete Czech is at variance with vivid tendencies of the contemporary norm and faraway from current colloquial Czech" (Daneš 1993: 224-225).
} 
Thus the most characteristic feature of the novel's language can be seen as a consequence of anecdotal storytelling. The use of the contemporary Czech language with its informal, vulgar idioms may not be derived primarily from the tradition of satire, and even less from the picaresque, but rather from the style of anecdotal storytelling that follows oral language use. As a result, anecdotalism can be said to be of greater significance than other genre components in terms of narrative style and storytelling.

In identifying the novel's genre components it is worth touching on additional aspects of anecdotalism. Attributing the polarizing perspective of Švejk exclusively to the tradition of satire would be a one-sided approach. One widely recognized use of the anecdote, and of anecdotal storytelling, is to present an unofficial view of history. The "great" events of officially recorded world history are traced back to ridiculous trifles, the petty and laughable personal faults of historical personalities, primitive motives and minor incidents, in contrast to the official, grandiose concept of history as narration. An example of the difference between "official" history and the worm's-eye view of events can be found in two works by the Byzantine historian Procopius, who wrote an unofficial history alongside the official annals commissioned by the emperor (Peri polemón, "On the wars"). The alternative history of the reign of Emperor Justinian depicts the great sovereign as an effeminate lecher and the majestic Empress Theodora as a vulgar, promiscuous and depraved courtesan. Through its various editions, Procopius's idiosyncratic historical work has become known under two different titles in European literary tradition: Historia arcana (A secret history) and Anekdota (Unpublished writings). This can be seen as a clear illustration of the thousand-year link between anecdotes and the concept of an unofficial view of history.

Švejk's stories, and the novel as a whole, present a worm's-eye view of history. In contrast to the official values, out of which inspirational and monumental myths are manufactured for the subjects of the Monarchy, the novel translates events into the language of the microcosm. This approach is most obvious in relation to events "with a significance in world history", such as the assassination of Franz Ferdinand, the Italians' entry into the war etc. Such events are paralleled by an anecdote from the world of the poor, with which Švejk is familiar. The de-heroization of history is also apparent in the parodying of war posters, the sermons preached at camp masses, and the way in which the officers speak. Great historical personalities become ridiculous figures when depicted by Švejk, volunteer Marek and the narrator. Švejk, for example, discusses Franz Ferdinand with one of his fellows:

"His Imperial Majesty must be completely off his rocker by this time", declared Švejk. "He was never bright, but this war'll certainly finish him."

"Of course he's off his rocker," the soldier from the barracks asserted with conviction. "He's so gaga he probably doesn't know there's a war on. Perhaps they're ashamed of telling him. If his signature's on the manifesto to his peoples, then it's a fraud. They 
must have had it printed without his knowledge, because he's not capable of thinking about anything at all."

"He is finished," added Švejk knowingly. "He wets himself and they have to feed him like a little baby. Recently a chap at the pub told us that His Imperial Majesty has two wet nurses and is breast-fed three times a day." (Hašek 1985: 207-208)

When talking about Friedrich Kraus a few pages earlier, the narrator makes similar comments about the emperor: "If we analyse his mental capacities, we reach the conclusion that they were not one wit better than those which had made the big-lipped Franz Joseph Hapsburg (sic!) celebrated as a patent idiot" (Hašek 1985: 202). The most striking example of a denial of official history is the regimental chronicle written by volunteer Marek, who delights in reading certain chapters out loud. These sarcastic and parodistic texts present a non-existent, fabricated history that exaggerates to extremes the obligatory dignified voice. Marek anticipates events by writing about the glorious deaths of various officers and soldiers. He takes huge pleasure in reading excerpts about their deaths to boorish officers or stupid soldiers, who listen with vacuous astonishment.

A worms-eye view of history presented in an anecdotal narrative is also a common feature in Hungarian literature. The tendency towards this viewpoint is probably influenced by the self-perception of the community, in which the fate of the nation is seen as the plaything of intransigent external powers. In this context, the nation as a whole is in a position analogous to that of the small people who are defenceless against a despot. For a community that assumes it is powerless to sway the decisions that affect it, the humorous depiction of authority is a way of relieving frustration. During the half century of the Austrian-Hungarian Monarchy, Hungary's relationship with Vienna was interpreted in the Hungarian historical consciousness not as one based on parity, but as a unique form of subordination. The other nations of the empire may have assumed that the state formation created by the 1867 Compromise was designed to ensure the supremacy of Austria and Hungary over the other provinces, nations and nationalities. However, to the Hungarian mind the connection with Austria was a devious and covert form of subordination, rather than joint rule based on equality between the two leading powers. From this perspective, the Monarchy failed to re-establish independent Hungarian statehood, which was lost after the fall of Buda in 1541. Self-interpretive narratives based on the image of a nation defenceless against external powers thus retained their relevance even after the Compromise. In Hungarian thinking, the 1867 Compromise was not a fair contract built on mutual advantages, but merely a new type of artifice. From a Czech perspective, national subordination was far more clearly manifested in the Monarchy. In Hašek's novel, the worm's-eye view of power is accompanied by definite anti-monarchist features. While the novel is wider in scope, it ridicules all forms of power and authoritarianism (Johnston, http://www.zenny.com/svejkcentral), and a national perspective is also apparent. 
Before a discussion of the Hungarian parallels can take place, it is necessary to touch briefly on the novel's interpretation of the anecdote. An approach that assumes two opposing concepts of the anecdote in the novel would seem justifiable. According to one concept, anecdotes are old-fashioned and worthless, while according to the other they are the basis of the narrative.

During the periods when Colonel Gerbich did not suffer attacks his office was full of the most diverse ranks, because in such exceptional circumstances he was very gay and talkative and was glad to have listeners around him to whom he could tell his dirty stories. This gave him a lot of pleasure and gave the others the satisfaction of being forced to laugh at his chestnuts, which were probably in circulation as long ago as the time of General Laudon. (Hašek 1985: 721) ${ }^{4}$

The old-fashioned nature of anecdotes is an important feature. Although the above quotation does not explain how the stories were old-fashioned, it is clear that the anecdotes did not belong to the present and were not about the present. It is also clear from the context that they were not capable of inspiring spontaneous laughter, since the subordinate officers' laughter is described as forced. The whole scene is redolent of the military hierarchy: the colonel's jokes are condescending, while his subordinates servilely pretend to be amused. This form of anecdote is used to enforce a position: only the colonel can tell these stories and no one is allowed to interrupt. The audience is forced to be passive, to accept its subordinate position, and to hide its real feelings. The reference to General Laudon may even be an allusion to military anecdotes that aim to present the greatness of military leaders and the cheerful side of a soldier's life.

The standoffish Sergeant Vaněk probably expects a similar story when he asks Švejk to recount an anecdote from military life. However, Švejk tells the rather anarchistic story of a cowardly soldier who, after giving it a drink, steals the statue of St John of Nepomuk that stands by the side of the road. Soon afterwards he suddenly enjoys a winning streak at cards, although subsequently loses everything. The consequences of the card game are described by Švejk: "When we moved off in the morning, St John of Nepomuk was strung up on the pear-tree by the road." He then abruptly ends the telephone conversation: "Well, that's your funny story, and now I'll put back the receiver again" (Hašek 1985: 443). ${ }^{5}$ Sergeant Vaněk can scarcely have expected this type of anecdote. The situation can be described as follows: Švejk, the narrator of the story, deliberately fails to fulfil his listener's expectations. A deputy officer asks an

${ }^{4}$ In the original Czech the word "anecdote" is used as the definition of the genre. "V dobách, kdy plukovník Gerbich netrpěl záchvaty, bývalo v jeho kanceláři vždy plno nejrùznějších šarží, nebot' on $\mathrm{v}$ takových mimořádných prŕípadec byl velice veselý a hovorný a rád měl kolem sebe posluchače, kterým by vypravoval sviňácké anekdoty, což mu dělalo velice dobře a ostatním působilo tu radost, že se nuceně smáli nad starými anekdotami, které snad byly v oběhu už za generála Laudona" (Hašek 1955: 689). Italics here and later in quotations from the original Czech are mine.

${ }^{5}$ The word anecdote is used in the Czech original: "Tak, to je ta anekdota a ted' zas zavěsim sluchátko" (Hašek 1955: 439). 
orderly to tell an anecdote, which also implies a hierarchical situation, although to a lesser extent than in the case of Gerbich and the subordinate officers. Although on the face of it Švejk fulfils the request of his superior, the sergeant, in reality he sabotages it. The story parodies the Catholic moral values that the Habsburg dynasty regarded as the keystone of the empire. Diatribes against the hypocritical military hierarchy and Catholicism are common in the voice of the narrator. Similarly, Švejk's stories often satirize these two cornerstones of authoritarian thinking. The episode is blasphemous in various respects. The soldier treats the statue of the saint first as a drinking companion, then as a lucky charm, before eventually "executing" it. The protagonist is a common man who, living in the present, reckons with Catholicism as an absolute authority on his own level. Thus the new type of anecdote has a subversive character: it questions, opposes and parodies the ideals and attitudes accepted by the authorities.

The subversive nature of anecdotes is most apparent in the story that Švejk tells to the sergeant in the Dobromil prison camp after the sergeant entertains him with a small show of his own. The sergeant instructs the orderly, Hans Löfler, to run around like a dog on all fours with a pipe in his mouth, then to round off the show by yodelling. The sergeant rewards this performance with four cigarettes. His goal was to demonstrate that the level of discipline was even higher in the K.u.K army than in the army of the Tsar. Švejk then begins his own story:

/... Švejk began to explain to him in his broken German that in one regiment an officer had an obedient batman like that who did everything his master wished, but when he was asked once whether, if his master ordered him to do so, he would eat his excrement out of a spoon, he said: 'If my lieutenant ordered me to do that I'd eat it according to his orders, always provided I didn't find a hair in it. If I did, it would disgust me frightfully and I should be sick at once.' (Hašek 1985: 674)

Švejk's anecdote is clearly a response to the events that have taken place before him. The story ridicules with scathing sarcasm the absurd servility he has just witnessed. Although the sergeant is too stupid to understand Švejk's story, he realizes its novelty. His words of appreciation ("You Jews have quite good stories $/ . . /$ " $)^{6}$ reveal that, for him, this type of anecdote is unusual, even foreign. He mistakenly attributes this strangeness to Švejk being Jewish and thus belonging to another culture and world.

The new type of anecdote implies a quiet resistance against the military hierarchy and authoritarianism. The unhurried style and wordiness of the narration are themselves a smiling rejection of military discipline. It is no coincidence that the fanatic First Lieutenant Dub-who is obsessed with authoritarianism-demands brevity and military laconicism from his men. The above-mentioned Sergeant Vaněk is anxious about the excessive spread of

6 "Vy židi máte podařené anekdoty /.../" (Hašek 1955: 648) 
anecdotes that is endangering military discipline. In his view, the continuous stream of anecdotes cannot be reconciled with military duty?

An important characteristic of the new type of anecdote that serves as the basis of the novel's narrative is the rejection of over-refinement and pomposity, which are regarded as hypocritical. As indicated in Hašek's often quoted epilogue, the rejection of both elegance and authoritarianism are interconnected in the novel. The words used in the epilogue to describe Palivec the innkeeper are true not only with respect to the character narrators of the inserted stories, but also, to a certain degree, the narrator of the novel himself: "It was in his blood-this lack of respect for the Emperor and for polite phrases" (Hašek 1985: 216).

In Hašek's novel, the new type of anecdote, which is a defining feature of the narrative, appears alongside old-fashioned anecdotes. In this respect it can be argued that the innovative approach in $\breve{S}$ vejk lies in the renewal of the anecdotal narrative. This feature of the text justifies the drawing of a parallel between this novel and the forms of anecdotal narrative that were widespread in $20^{\text {th }}$-century Hungarian prose. Thus Hungarian tradition did not continue the anecdotal prose of the $19^{\text {th }}$ century unchanged, but renewed and reinterpreted it.

Gyula Krúdy can be considered as the most significant representative of this renewed and reinterpreted anecdotal narrative in early $20^{\text {th }}$-century Hungary. However, the present comparative analysis will focus on Józsi Jenő Tersánszky, rather than Krúdy, due to the numerous connections that apparently exist between the narrative in certain of Tersánszky's works and that of the renowned Czech novel. The fact that Krúdy's possibly most significant novel, Boldogult úrfikoromban (In my early youth) (1930) is closer to Švejk in important structural aspects than any of Tersánszky's works does not contradict the above claim. A remarkable proportion of Švejk is made up of the protagonist's anecdotes and, to a lesser extent, inserted stories told by other characters. This structure is obviously similar to that used in Krúdy's novel, which can be considered as a compilation of anecdotal stories recounted around a pub table. Another similarity between the narrative structure adopted by the two authors is the imitation of the picaresque novel, which is explicit in a number of Krúdy's works such as Szindbád ifjúsága (Sindbad's youth) (1911), De Ronch kapitány csoldálatos

\footnotetext{
7 "The N.C.O.s would have to give me the company's complement twice a day. But what can you do when the N.C.O.s are utterly incompetent. The worst of all in our company is that platoon sergeant Zyka. All he does is to make jokes and tell stories, and when he's told that Kolařík has been assigned away from his platoon to the baggage train, he reports to me next day the same complement, as though Kolařík had gone on loafing about in the company and in his platoon. And when that happens every day and on top of that I'm told a bloody mule..." (Hašek 1985: 477-478)

"Ale když šarže nejsou k ničemu. A nejhorší u nás ten cuksfíra Zyka. Samý žert, samá anekdota, ale když mu oznamuji, že je Kolařík odkomandován z jeho cuku k trénu, hlásí mi druhý den zas týž samý stand, jako by Kolařík dál se válel u kompanie a u jeho cuku. A když se to má opakovat denné a potom ještě o mně říct, že jsem mezek..." (Hašek 1955: 470)
} 
kalandjai (The marvellous adventures of Captain de Ronch) (1912) and even The Crimson Coach (1913). Krúdy's short stories, short story cycles and novels imitate the picaresque tradition more closely than $\check{S} v e j k$, as the narrator mentions in turn classics of the genre such as Gil Blas and The Lame Devil.

Beside these apparent parallels there are, however, a number of fundamental differences, and these differences are less significant in the case of Tersánszky. One decisive difference is the fact that Krúdy's narrative moves away from plot-driven prose. A complex plot is not one of the key elements of his prose, plot being overshadowed by the linguistic creativity of the narration. In the majority of his novels the story is fragmented, and in most cases there is almost no plot - in the traditional sense. The decorative and stylistic tendencies of aestheticism also strongly influenced Krúdy's texts, along with the tendency of anecdotal narrative to imitate living speech.

With its artistic, lengthy and complex sentences, striking metaphors and prolific similes, his narrative style was described as lyrical prose by literary critics at the turn of the century. Such aestheticism is entirely foreign to the text of Švejk. In fact, Hašek famously mocked refined aesthetes in the epilogue to the novel. Metaphorical meaning plays an important role in Krúdy's works, while Švejk prefers strident unambiguity to hidden meaning. There is little point looking for metaphorical meanings in a novel that claims satirical candour. Another difference is that the structure of $\breve{S} v e j k$ is linear: events follow one another chronologically, resulting in a simple and transparent temporal structure. Krúdy, however, is a writer of memory. The narrative voices of both his characters and his works tend to start on the path of associative remembrance.

The real time of the plot is overshadowed by layers of spontaneously recalled memories, which are connected to one another by the irregular play of remembrance rather than chronology. Another characteristic of Krúdy's handling of time is the fact that narrative time is frequently accentuated, while in Švejk it is rarely given emphasis. ${ }^{8}$ Hašek's novel adopts a satirical approach, and, as a result, presents a fixed set of values. Krúdy's works are written from a more realistic viewpoint and thus do not judge between right and wrong. They suggest that life is inherently meaningless, and they accept this realization with humorous resignation. Finally, the radical difference in the presentation of the Monarchy in the two oeuvres also deserves mention. Švejk is convinced that "A monarchy as idiotic as this ought not to exist at all" (Hašek 1985: 208), while in Krúdy's works the figure of Franz Joseph and his disappearing world are treated with ridicule and nostalgia simultaneously. At the same time, that world is not presented as a real historical period but rather as one created by fiction.

${ }^{8}$ For example in places where the narrator refers to Švejk as a personal acquaintance and remembers the good soldier who, even now, recounts his wartime experiences with pleasure. 
The most evident parallel to Švejk among Tersánszky’s novels is Egy ceruza története (The story of a pencil) (1948). ${ }^{9}$ The novel is also set in the First World War: events take place during the Battle of the Piave River. Its playful humour is already apparent in the very concept of a novel narrated by an indelible pencil. The pencil recounts its experiences with various owners and describes the letters and notes that have been written with it. This concept makes possible the introduction of various characters of different positions and diverse national and social status within the relatively short space of 200 pages. As the pencil constantly changes owner, the story is freed from the requirement to fulfil readers' expectations of a highly coherent plot structure, thus, similarly to $\breve{S} v e j k$, the novel is episodic. The majority of episodes are of an anecdotal character, as, for example, the account of the death of four soldiers who were in fact killed by a fly. Sir Abrakovszky is disturbed by a fly while considering the soldiers' request for leave. When the fly bites his hand he accidentally breaks his gold-tipped pen in his anger and is forced to delay signing the papers in front of him. Thus the four Hungarian soldiers, who were waiting for permission to go on leave, have no choice but to return to the front from the regimental headquarters. As they are unaware that the Italian artillery fires at the same ruined farmhouse precisely at noon each day-something that is common knowledge at the headquarters - they are killed as they pass the building. When Sir Abrakovszky finds out about their deaths he is forced to acknowledge the hidden link between events and immediately orders a consignment of fly-paper. The story of the seven heroes who drowned in wine is also redolent of the Švejk-type anecdote. The soldiers die in an Italian cellar during an earlier offensive when wine, escaping from damaged barrels, rises to a depth of one metre. The soldiers' bodies are discovered several days later by their companions: the bodies are left exposed when the pool of wine is drained by being drunk from their billy-cans. The love story of Lieutenant Gaffner forms another anecdotal episode. Gina, a lascivious peasant girl, aims to seduce the young virgin cadet. In such times of shortage the cadet plans to present the girl with a gift of fat. However, when he goes to meet her he realizes that he has left the jar of fat behind. He can think of nothing else and is so distracted that he is quite unable to perform. When he returns to his quarters he confesses to the orderly, who had organized the meeting, that nothing happened. Miska, who is also involved with Gina, takes Gaffner back to the girl's room. Gina, however, is tired and responds sleepily to the sexual advances, thinking that her midnight visitor is Miska. She only realizes her mistake - the fact that her guest was Cadet Gaffner-the next day. The anecdote involving Balbo also ends with a punchline. Filled with patriotism the teenage boy risks his life by swimming to the Italian side of the Piave River in secret to inform the Italian commanders of the planned Austrian offensive. When he reveals the details of the battle plan to the first Italian sergeant he meets, the soldier laughs at him

${ }^{9}$ This parallel was first suggested by László Rónay in his monograph on Tersánszky (Rónay 1983: 245). 
and mockingly fills in the remaining details, adding: "Look, boy, I can tell you our commanders' counter-offensive right now" (Tersánszky 1975: 136). ${ }^{10}$ Thus the details of the battle plan, drawn up in the utmost secrecy, are actually common knowledge, although the Austrian commanders are entirely unaware of the fact. To round off the list of anecdotal episodes, it should also be mentioned that the entire offensive - that is, the "macro-plot" itself-is of an anecdotal character. The brigadier general tells his officers that the "strategic objective" of the offensive is to acquire the Italians' supplies of thread.

In this last scene, the discrepancy between the grand historical narrative and the anecdotal approach is made particularly apparent. The brigadier general asks his officers to guess the objective of the offensive. Each response refers to a serious, strategic goal: the occupying of railways, bridges or roads; the diversion of forces from the planned Entente attack against the Germans; the possibility of an independent peace treaty for the Monarchy; the opening up of a new front behind the French, etc. Such objectives, familiar from the pages of military history and apparently plausible from the perspective of military tactics and world policy, are swept away by the brigadier general, who reveals a far simpler goal: "We have no thread! This is the Thread Offensive" (Tersánszky 1975: 98). Another characteristic method of invalidating a grand narration of history that promises to explore the larger context is to emphasize arbitrariness. Events are presented as a sequence of accidents and coincidences, rather than as the result of causal chains. The deaths of the four Hungarian soldiers who had requested leave but who were killed by canon fire was the result of two accidents: Abrakovszky was bitten by a fly, and the group of soldiers passed the ruined farmhouse precisely at noon. Lieutenant Kabarcsik, who can even be regarded as the protagonist of the novel due to the length of his notes, survives being struck by shrapnel only because the splinter ricochets off his notebook - and the pencil attached to it—before hitting the buckle on his braces. The pencil adds the following comment: "There you have it! What saves one's life! A braces buckle, a notebook and a poor, injured pencil brother of mine" (Tersánszky 1975: 81). The concept of accidentality is also reflected in the episodic structure of the novel, which is similar to that of $\check{S} v e j k$.

Like Hašek's novel, The Story of a Pencil also invalidates official social values. The narrative treats with reservations the myths of blood ties and nationalism. The narrator accepts, for example, that the Italian population hopes for Austrian victory, as they will only be able to get food if the front collapses but will otherwise die of starvation. Kabarcsik, who has long been planning to write a war novel, does not in the end write his book, refusing to fulfil official expectations:

But Kabarcsik, who should be praised for this — being the master of lying and pretencewas almost puritan with a pen in his hand. For him it was simply unacceptable to write a war novel in which soldiers die on the battlefield with the name of the fatherland and the emperor on their lips." (Tersánszky 1975: 84)

${ }^{10}$ Further page references are given in parentheses within the body text. 
In other respects, too, the novel fails to uphold the official moral principles of society. The narrator expresses no disapproval of the prostitute who openly admits that she has chosen this line of work because she earns more than she did while working as a governess. He treats Gina's promiscuity with the same understanding. Nor are the two most prominent characters in the novel, Kabarcsik and his servant, beyond reproach. They, like Švejk, live on the margins of society: Kabarcsik is a gambler, a womanizer, a swindler, a failed playwright who "no longer pursues" his sham literary career. His enterprising orderly, Gyurka, whose foresight saves the life of the wounded Doctor Lehman, is a pickpocket in civilian life. The novel, like many of Tersánszky's works, posits a form of natural law that runs counter to the official morals of society. It permits individuals to break social rules in order to make a living, or in the interests of a particular lifestyle, but only as far as is necessary and in such a way that causes the least possible harm to others.

Along with anecdotal features, the most important similarity between the two novels lies in the style of the narrative. The quotation from František Daneš above already referred to the innovative use of everyday, colloquial Czech in the second version of Švejk as a significant landmark in literary history. A corresponding version of this style, at a linguistic level below that of conversational language, can also be found in Tersánszky's narrative. Tersánszky created a unique, natural-sounding, individual language in his works. In Hungarian literature it was he, and possibly Ernö Szép from the first half of the $20^{\text {th }}$ century, who went furthest in challenging the attitude that the text of the literary work was a linguistic norm. He augmented the typically loose sentence structure and colloquialism of the traditional anecdotal narrative with argot and slang. Such a linguistic register itself emphasizes the individual's position on the margins of society. This narrative feature suggests that not only Tersánszky's characters, but also the narrator, position themselves outside society. They are not rebels, merely peaceful anarchists who do not believe in any social system, or in the possibility of a more just society. To conform to social expectations they maintain appearances only to the extent that is absolutely necessary. This approach is illustrated by the prostitute in The Marguerite Song: "Do whatever you want, then shut up" (Tersánszky 1991: 10).

Following this brief summary of the parallels between the two novels, it is worth mentioning some of the dissimilarities. One fundamental difference is the fact that the notes written by Lieutenant Kabarcsik during the offensive-which make up almost a quarter of the novel — are not typical of anecdotal narrative, with the exception of Kabarcsik's summary of lessons learned. Towards the end of his notes, he writes in true anecdotal style: "I have to admit, this enterprise is one hundred percent Austro-Hungarian military fact. The offensive failed quite literally, but the retreat was a great success" (Tersánszky 1975: 220). When narrating events from the frontline, there is a significant reduction in the humour of Kabarcsik's notes, which is replaced by shocking accounts of first-hand experience. This type of self-narration is analogous to the selfobserving narrative of the psychological novel and has little in common with 
anecdotal narrative. Tersánszky's novel is also significantly less satirical, and less provocative, than $\breve{S} v e j k$, and the role of vulgarisms is limited. Although both novels approach the First World War as the beginning of the end of the AustroHungarian Empire, this historical event is presented very differently in each. Švejk attacks the Monarchy with satirical vehemence, while Tersánszky's book chronicles the end of the Empire and the shock experienced by the characters and the narrator as a result of the radical change in their community's fate. What lies behind this difference is the divergence between the Hungarian and Czech perspectives within the Monarchy, based on the different roles played by the two nations within the Empire. The post-war peace treaties allowed the Czech nation to establish independent statehood, while Hungary lost two-thirds of its territory and a large proportion of the Hungarian ethnic population was left outside the new national borders. From this perspective it is not surprising that the dismantling of the Monarchy was not greeted with euphoria. Kabarcsik's notes summarize a position in which relations with Austria are examined critically, while the disadvantages of the end of the Monarchy are also taken into consideration: "It doesn't really matter to us if we win or lose. For us, it's bad whatever happens" (Tersánszky 1975: 167).

Setting aside the similarities arising from the common theme of war, Tersánszky's Kakuk Marci novels (1922-1941) contain the most numerous parallels with $\check{S}$ vejk from a purely stylistic point of view. Due to the episodic structure, the elements of the plot are only loosely connected. Causality, like chronological order, has no significant role in the structure of the novels, and certain episodes are even interchangeable. The personality of the protagonist remains static: he does not undergo any significant change in the course of events, and the plot is not designed to endow his personality with any psychological depth or complexity. The novels do not employ the tools of psychological narrative: they focus on the narration of external events, adventures and episodes rather than on the inner world of their characters. In addition to the obvious traits of anecdotal narrative (oral character, narrative tendency, leisurely pace, comic tone, anecdotal episodes, familial relationships), their narrative is reminiscent of the picaresque novel (Angyalosi 1996: 72-74), to an even greater extent than in the case of Švejk. The vagrant, womanizing protagonist of the Kakuk Marci novels relates his past adventures in a first-person retrospective narrative, while this conventional characteristic of the genre is not adopted in Hašek's novel. Nevertheless, the common feature of Švejk and the Kakuk Marci novels is the transformation of the protagonist's position. Neither Švejk nor Kakuk Marci fit into the traditional role of the picaro. They certainly resemble the picaro in terms of their position on the margins of society and their questionable conformity to social morals, yet both of them lack any ambition to climb through the social ranks. They are content with little and are happy to be left in peace and to eat and drink well. (An ardent love life enhances the feeling of happiness in Kakuk Marci's case, as suggested by the protagonist's name "Martin Cuckoo".) The two protagonists are alike in being humble and modest and having a relaxed attitude to life. Thus both works of fiction can be said 
to follow the picaresque tradition while also diverging from the rules of the genre. However, there are certain differences between them: one of the most fascinating aspects of Švejk is that he combines the traits of the idiot with cunning and wit. Kakuk Marci is far more intelligent than those around him: his success with women is typically due to his guile, which gets him out of many awkward situations. He deliberately chooses to be a vagrant: his position in society is the result of his own decision. On many occasions he is offered a socially acceptable status, but he always escapes the bonds that such a status would represent. Kakuk Marci is the essential incarnation of Tersánszky's gentle, smiling anarchist. His extravagance is conveyed in the way he speaks: the idiosyncratic style of Tersánszky that was noted above first appeared in the pages of the Kakuk Marci novels.

If Kakuk Marci is the wise half of Švejk's wise fool, then the foolish half is Gazsi, the protagonist of the short novel Legenda a nyúlpaprikásról (The legend of the rabbit stew) (1936). Gazsi is a village idiot who is despised by everyone, but he also has an instinctive love of life despite his poverty and suffering. Although the narrator often mocks Gazsi's mental deficiencies with condescending tolerance, he presents Gazsi's modesty, marginality, freedom from materialism and goodness towards all living things as an example to be followed. His story - as the title suggests - is presented as a profane, secular legend. The concept of a religious moral or other metaphysical reference is entirely lacking. Although this viewpoint is not identical to the obvious anticlericalism of $\tilde{S} v e j k$, it still invalidates the religious perspective. The narrator is critical of the other characters in the novel. He describes the countess, for example, as hysterical and refers to all her actions as indicative of exaltation. When Gazsi shows her the tamed rabbit, Paprikás, the countess immediately has a vision of medieval saints and sees a halo around Gazsi's head. This exalted view is invalidated by the narrator by means of the measured assessment that precedes the passage describing the countess's visions:

The countess had truly forgotten that she had seen hundreds of better acts performed by circus, speaking, counting, cancan-dancing, bike-riding, cigar-smoking and card-playing animals in the blinding electric light of metropolitan arenas and music halls.

The countess stood in the sunshine under a totally different spell. She was thinking of the myths and legends of her childhood, about holy saints, whom the wild animals of the forest approached with trust, and who preached the word of goodness and mercy to the birds of the sky... It was as if the countess had seen a halo around the sparse, grey hair of this old pig keeper, grinning beatifically in his rags. (Tersánszky 1982: 242)

Gazsi's naivety is a profane, grotesque reflection of the medieval sancta simplicitas, based not on transcendence but on the quiet joy of life and the vitality of the body. The novel thus evokes the figure of St Francis of Assisi with slightly blasphemous implications. The text quoted above alludes to the stories of the wolf of Gubbio and of Francis preaching to the birds-immortalized in Giotto's famous painting. However, here the founder of the mendicant order is replaced by the village beggar, whose filth and stench are also described in the 
narrative. The naivety of St Francis is turned into a maxim, an unwillingness to expect evil from another human being even after the repeated experience of hatred. In accordance with Christian teachings, Gazsi also turns the other cheek. While this attitude is derived from the imitation of Christ, Gazsi's goodness is not the moral consequence of a conscious naivety. It is, instead, a natural trait, the fact that his undeveloped intellect conceals fewer ulterior motives than in others. The spontaneous sympathy that he feels towards other creatures is a manifestation of his very nature, while Saint Francis adopted naivety consciously, having realized the common status of all beings, in the form of a religious conviction. In contrast to Švejk, Gazsi is a harmless figure. He does not cause trouble accidentally or willingly, he does not provoke his superiors, he does not humiliate peers with lesser intellects than his own, and there is no reason to believe that his mental disability is a sham. However, Gazsi and Švejk are akin in their natural joy in life that manifests itself in their naivety, and which is presented in both novels as a natural human trait. Anecdotalism, and a serene approach to life that is not without features of the grotesque, are connected in the prose of both Hašek and Tersánszky.

The history of the anecdotal narrative can be seen as relevant not only in the examination of the Central European literature in the first half of the $20^{\text {th }}$ century. Such a comparative approach may cover a significantly wider field. To continue the Czech-Hungarian parallel, the fundamentally renewed and transformed variants of anecdotal narrative in the works of two internationally acknowledged writers from the region, Bohumil Hrabal and Péter Esterházy, should also be mentioned. These two examples provide convincing proof that the history of the anecdotal narrative continues up to the present day. It would therefore seem justifiable to assert that anecdotal narrative can serve as a basis for the comparative study of prose from literary periods both before and after that examined in the present paper. The possibility that the variants of anecdotal prose may deserve a separate chapter in the comparative history of Central European literature must also be considered.

\section{BIBLIOGRAFIJA}

Gergely ANGYALOSI, 1996: A költő hét bordája [The Poet's Seven Ribs]. Debrecen: Latin Betük.

František DANEŠ, 1993: The Language and Style of Hašek's Novel 'The Good Soldier Švejk' from the Viewpoint of Translation. Studies in Functional Linguistics. Ed. by Jan Chloupek and Jiři Nekvapil. Amsterdam: John Benjamins Publishing Company.

Péter HAJDÚ, 2005: Csak egyet, de kétszer. A Mikszáth-próza kérdései [Only one but twice. Questions on Mikszáth's prose]. Budapest - Szeged: Gondolat—Pompeji.

Jaroslav HAŠEK, 1955: Osudy dobrého vojáka Švehja za světové vláky. Prague: PráceVydavatestvo Roh. 
--, 1985: The Good Soldier Švejk and his Fortunes in the World War. Transl. by Cecil Parrot, Bungay: Penguin Books.

Ian JOHNSTON, On Hašek's The Good Soldier Švejk. http://www.zenny.com/svejkcentral/ (Download date: 21. 09. 2015.)

Thomas KOVACH, 1984: Hašek's Good Soldier Švejk as a Picaresque Novel. Germano-Slavica 4/5, 251-261.

László RÓNAY, 1983: Tersánszky Józsi Jenő. Budapest: Gondolat.

Peter STEINER, 2000: The Desert of Bohemia. Czech Fiction and its Social Context. Ithaca: Cornell University.

Józsi Jenő TERSÁNSZKY, 1975: Három történet [Three Stories]. Budapest: Magvető. - -, 1982: Viszontlátásra, drága-Legenda a nyúlpaprikásról [Goodbye, Dear - The Legend of the Rabbit Stew]. Budapest: Magvető.

- -, 1991: A margarétás dal [The Marguerite Song]. Budapest: Szépirodalmi.

\section{MADŽARSKE VZPOREDNICE ANEKDOTIČNEMU STILU V ŠVEJKU}

Med žanrskimi komponentami Švejka je že dolgo evidentirana anekdota, vendar so pri anekdotičnosti večinoma poudarjene posebnosti, ki roman povezujejo z menipsko satiro in pikaresknim romanom, in to kljub temu, da roman ne izpolnjuje vseh kriterijev omenjenih žanrov. Pri anekdotičnem romanu pa omejevanje pri rabi termina ni potrebno. V predvojnih različicah Švejka ni anekdotičnih zgodb, ki jih pripoveduje glavna oseba, dobri vojak govori splošni pogovorni jezik in ne vsakdanjega nižje pogovornega jezika. To pomeni, da je naracijo končne verzije romana temeljito spremenil ustni značaj anekdotičnega načina pripovedovanja in prav zaradi tega moramo anekdotičnosti priznati ključno vlogo med žanrskimi komponentami besedila. Haškov roman sledi satirični orkestraciji anekdotične tradicije, ki se je širila in postala popularna s posredovanjem Prokopove Historie arcane ali drugače Anekdote, v kateri avtor pripoveduje neuradno zgodovino oblasti cesarja Justinijana. V Haškovem romanu je anekdota žanr subverzivnega pristopa, anekdotične zgodbe, ki jih predstavljata glavni lik in pripovedovalec, na provokativen način odklanjajo uradne vrednote in pogled na zgodovino. Najvidnejša madžarska vzporednica Švejka je Tersánszkyjev roman Zgodba o svinčniku, ki se dogaja $\mathrm{v}$ času prve svetovne vojne in ki na podoben način dvomi o velikih zgodovinskih zgodbah. Tersánszkyjeva ustna pripoved vsebuje elemente, ki so podobni slengu, namenoma krši pravila splošnega pogovornega jezika. To kršenje pravil je povezano s pozicijo pripovedovalca in njegovih junakov izven družbe. Tersánszkyjevi najbolj karakteristični junaki (kakršen je npr. tudi glavni junak v ciklu romana Marci Kakuk) so molčeči anarhisti, ki nočejo spremeniti družbenega reda, odklanjajo vsako nasilje, hkrati pa menijo, da predpisana družbena pravila za njih niso obvezujoča. Zanje je značilen spontani vitalizem, zadovoljni so z malenkostmi, podobno kot dobri vojak. Ne želijo doseči visokega položaja v družbi ali si ustvariti kariere, zadovoljijo se z vsakdanjimi radostmi in dvomijo o velikih oz. junaških življenjskih in vrednostnih nazorih. 